\title{
Implementasi Metode Simple Additive Weighting (SAW) dan Technique for Order Preference by Similariy to Ideal Solution (TOPSIS) pada Penerimaan Karyawan
} (Studi Kasus : PT. Seikou Seat Cover)

\author{
Sri Kurniasih ${ }^{1}$, Olvi Oktavia ${ }^{2}$ \\ ${ }^{1,2}$ Program Studi Sistem Informasi \\ ${ }^{1,2}$ STMIK LPKIA Bandung, Jl. Soekarno Hatta No. 456 Bandung, Jawa Barat \\ Email : srikurniasihmkom@gmail.com ${ }^{1}$, 150513024olvioktavia@gmail.com²
}

\begin{abstract}
ABSTRAK
Karyawan merupakan sumber daya manusia yang sangat penting dalam suatu perusahaan. Tujuan diadakannya rekrutmen adalah untuk mencari calon karyawan dengan kriteria tertentu dalam memenuhi kebutuhan sumber daya manusia di perusahaan. Penelitian ini bertujuan untuk membantu pihak perusahaan dalam proses penerimaan karyawan menggunakan sistem pendukung keputusan dengan tujuan dapat merekomendasikan pihak perusahaan dalam menentukan posisi/jabatan yang sesuai dengan kriteria pelamar.

Sistem pendukung keputusan ini menggunakan metode Simple Additive Weighting (SAW) dan Technique for Order Preference by Similarity to Ideal Solution (TOPSIS). SAW digunakan dalam mencari pejumlahan terbobot dari rating kinerja setiap alternatif, melakukan normalisasi matrik keputusan dan perankingan untuk menghasikan lima alternatif tertinggi dari yang terpilih. Sedangkan metode TOPSIS digunakan untuk menghitung setiap alternatif terpilih untuk menghasilkan rekomendasi posisi/jabatan bagi pelamar. Dalam membangun perangkat lunaknya menggunakan bahasa pemrograman PHP dan server database yang digunakan terdiri dari XAMPP dan MySQL.

Hasil dari penelitian ini berupa sebuah sistem pendukung keputusan yang dapat membantu pihak perusahaan dalam menentukan proses penerimaan karyawan dan merekomendasikan posisi/jabatan untuk pelamar sesuai dengan penilaian kriteria dari masing-masing pelamar.
\end{abstract}

Kata kunci: SPK, SAW, TOPSIS, Karyawan, Rekrutmen

\section{ABSTRACT}

Employees are a very important human resource in a company. The purpose of holding recruitment is to find prospective employees with certain criteria in meeting the human resource needs of the company. This study aims to assist the company in the process of hiring employees using a decision support system with the aim of being able to recommend the company in determining the position / position that matches the applicant's criteria.

This decision support system uses the Simple Additive Weighting (SAW) method and the Technique for Order Preference by Similarity to Ideal Solution (TOPSIS). SAW is used in finding the weighted sum of the performance ratings of each alternative, normalizing the decision matrix and ranking it to produce the fifth highest alternatives from the chosen ones. Meanwhile, the TOPSIS method is used to calculate each selected 
alternative to produce a position recommendation for applicants. In building the software using the PHP programming language and the database server used consists of XAMPP and MYSQL.

The result of this study are in the form of a decission support system that can assist the company in determining the recruitment process and recommending positions for applicants to the assessment criteria of each applicant.

Keywords : SPK, SAW, TOPSIS, Employees, Recruitment

\section{PENDAHULUAN}

Karyawan merupakan sumber daya manusia yang sangat penting dalam suatu perusahaan, karena karyawan memiliki pengaruh dan peran dalam setiap aktivitas untuk mencapai tujuan perusahaan. Rekrutmen adalah suatu proses untuk mencari calon karyawan dengan karakteristik tertentu untuk memenuhi kebutuhan sumber daya manusia di perusahaan. Dalam hal rekrutmen, perusahaan perlu melakukan perencanaan sumber daya manusia guna memenuhi kebutuhan akan sumber daya manusianya. Perkembangan perusahaan sangat dipengaruhi oleh jumlah pekerja yang bekerja dengan ditandainya jumlah yang melamar pekerjaan. Seiring dengan bertambahnya jumlah calon karyawan yang bekerja, hal ini berpengaruh pada pengambilan keputusan untuk menentukan pelamar untuk menempati jabatan tertentu. Selain itu kriteria karyawan semakin kompleks hingga sangat sulit untuk memilih pelamar yang dapat memenuhi jabatan sesuai dengan harapan perusahaan.

PT Seikou Seat Cover merupakan perusahaan industri garmen yang bergerak dibidang pembuatan barang jadi tekstil, selain pakaian jadi yaitu cover jok, kursi pijat dengan tujuan ekspor ke negara Jepang. Tentunya banyak pelamar yang ingin bekerja di PT Seikou. Proses penerimaan karyawan yang berjalan di perusahaan belum menerapkan pemanfaatan teknologi terkini. Dalam proses perhitungan hasil tes tertulis misalnya, hal ini masih dilakukan dengan cara manual menggunakan alat bantu kalkulator yang memungkinkan terjadinya kesalahan dalam menghitung hasil tes. Hasil tes tertulis sangat berpengaruh terhadap penilaian pelamar untuk lolos ke tahap tes selanjutnya. Sehingga jika terjadi kesalahan dalam proses perhitungan dapat merugikan perusahaan dalam menentukan karyawan yang sesuai dengan posisi dan kriteria yang diinginkan. 
PT. Seikou Seat Cover memerlukan sebuah sistem untuk mempermudah dalam pengambilan keputusan khususnya pada bagian HRD yaitu dalam proses perhitungan secara komputasi yang lebih sederhana dan efisien dalam menyeleksi pelamar terbaik. Sistem ini juga diharapkan mampu mempermudah manajer dalam merekomendasikan dan mempertimbangan pelamar untuk menentukan posisi/jabatan yang sesuai dengan kriteria yang diinginkan oleh perusahaan, sehingga proses ini menjadi lebih cepat dan akurat. Berdasarkan latar belakang yang ada, maka dapat diidentifikasi permasalahan pada bagian HRD yaitu proses penerimaan calon karyawan yang belum dapat ditangani dengan cepat karena perhitungan hasil tes tertulis calon karyawan masih dilakukan dengan cara konvensional. Hal ini mengakibatkan bagian HRD membutuhkan waktu yang cukup banyak dalam penanganannya karena jumlah pelamar ke perusahaan ini juga cukup banyak. Selain itu belum adanya sistem penerimaan karyawan yang bisa menangani dengan cepat untuk menentukan posisi atau jabatan karyawan.

Dengan adanya sistem pendukung keputusan maka proses penerimaan lamaran calon karyawan sampai dengan proses penentuan posisi/jabatan karyawan dapat dibantu dan ditangani dengan cepat karena, sistem yang dirancang akan membantu proses penerimaan calon karyawan dimulai dari penerimaan data pelamar, input soal tes oleh pelamar sampai dengan koreksi hasil tes akan muncul secara otomatis. Selain itu sistem akan di lengkapi dengan fitur-fitur informasi sehingga memudahkan pelamar dan bagian HRD dalam penanganan proses penerimaan calon karyawan.

\section{LANDASAN TEORI}

Bab ini akan menjelaskan mengenai teori tentang permasalahan agar lebih memahami tentang permasalahan yang akan dibahas dalam jurnal ini serta pembahasan mengenai teknologi dan metodologi yang digunakan terkait langsung dengan permasalahan yang terjadi di PT. Seikou Seat Cover.

\subsection{Sistem Pendukung Keputusan}

Menurut (Kurniasih, S \& Astuti, SP, 2020) yang mengutip pernyataan Nofriansyah \& Defit mengenai pengertian sistem pendukung keputusan menyatakan bahwa "Sistem pendukung keputusan adalah suatu informasi spesifik yang ditujukan 
untuk membantu manajemen dalam mengambil keputusan yang berkaitan dengan persoalan yang bersifat semi terstruktur."

Menurut (Eniyati, 2011) menjelaskan bahwa sistem pendukung keputusan adalah suatu sistem berbasis komputer yang menghasilkan berbagai alternatif keputusan untuk membantu manajemen mengenai berbagai permasalahan yang terstruktur ataupun tidak terstruktur dengan menggunakan data dan model." Sedangkan untuk menghasilkan keputusan yang baik ada beberapa tahapan proses yang harus dilalui dalam pengambilan keputusan. Tahapannya sebagai berikut :

1. Tahap Penelusuran (Intelligence)

Tahap ini pengambilan keputusan mempelajari kenyataan yang terjadi, sehingga kita bisa mengidentifikasi masalah yang terjadi biasanya dilakukan analisis dari sistem ke subsistem pembentuknya sehingga didapatkan keluaran berupa dokumen pernyataan masalah.

2. Tahap Desain

Dalam tahap ini pengambil keputusan menemukan, mengembangkan dan menganalisis semua pemecahan yang mungkin yaitu melalui pembuatan model yang bisa mewakili kondisi nyata masalah. Dari tahap ini didapatkan keluaran berapa dokumen alternatif solusi.

3. Tahap Choice

Dalam tahap ini pengambil keputusan memiliki salah satu alternatif pemecahan yang di buat pada tahap desain yang dipandang sebagai aksi yang paling tepat untuk mengatasi masalah yang sedang dihadapi. Dari tahap ini didapatkan dokumen solusi dan rencana implementasinya.

4. Tahap Implementation

Pengambil keputusan menjalankan rangkaian aksi pemecahan yang dipilih di tahap choice. Implementasi yang sukses ditandai dengan terjawabnya masalah yang dihadapi, sementara kegagalan ditandai masih adanya masalah yang sedang dicoba untuk diatasi. Dari tahap ini didapatkan laporan pelaksanaan solusi dan hasilnya.

\subsection{Simple Additive Weighting (SAW)}

Menurut (Kusumadewi, 2006) bahwa : "Metode SAW sering dikenal dengan istilah metode penjumlahan terbobot, konsep dasar metode SAW adalah mencari 
penjumlahan terbobot dari rating kinerja pada setiap alternatif pada semua atribut, metode SAW membutuhkan proses normalisasi matriks keputusan ke suatu skala yang dapat diperbandingkan dengan semua rating alternatif yang ada."

Adapun langkah penyelesaian dalam menggunakan metode SAW adalah :

1. Menampilkan alternatif (kandidat), yaitu Ai.

2. Menentukan kriteria yang akan dijadikan acuan dalam pengambilan keputusan, yaitu $\mathrm{Cj}$.

3. Memberikan nilai rating kecocokan setiap alternatif pada setiap kriteria.

4. Menentukan bobot preferensi atau tingkat kepentingan (w) setiap kriteria $\mathrm{W}=$ $[\mathrm{W} 1, \mathrm{~W} 2, \mathrm{~W} 3, \ldots \mathrm{Wj}]$.

5. Membuat tabel rating kecocokan dari setiap alternatif pada setiap kriteria

6. Membuat matriks keputusan $\mathrm{X}$ yang dibentuk dari table rating kecocokan dari setiap alternatif pada setiap kriteria. Nilai x setiap alternatif (Ai) pada setiap kriteria (Cj) yang sudah di tentukan, dimana, , $i=1,2, \ldots \mathrm{m}$ dan $\mathrm{j}=1,2, \ldots . \mathrm{n}$.

$$
x=\left[\begin{array}{ccc}
x_{11} & \cdots & x_{1 j} \\
\vdots & \ddots & \vdots \\
x_{i 1} & \cdots & x_{i j}
\end{array}\right] \text { (2) }
$$

7. Melakukan normalisasi matriks keputusan $\mathrm{X}$ dengan cara menghitung nilai rating kinerja ternormalisasi (Rij) dari alternative Ai pada kriteria $\mathrm{Cj}$.

$$
r_{i j}=\left\{\begin{array}{l}
\frac{x_{i j}}{\operatorname{Max}\left(x_{i j}\right)} \\
\frac{\operatorname{Min}_{i}\left(x_{i j}\right)}{x_{i j}}
\end{array}\right.
$$

Jika j adalah kriteria keuntungan (benefit), apabila nilai xij memberikan keuntungan bagi pengambil keputusan, sebaliknya kriteria biaya apabila xij menimbukan biaya bagi pengambil keputusan

Jika j adalah kriteria biaya (cost), Apabila berupa kriteria keuntungan maka nilai xj dibagi dengan nilai Maxi(Xij) dari setiap kolom,sedangkan untuk kriteria biaya, nilai Mini(Xij) dari setiap kolom dibagi dengan nilai Xij.

8. Hasil dari nilai rating kinerja ternormalisasi (rij) membentuk matrik ternormalisasi $(\mathrm{R})$.

$$
R=\left[\begin{array}{ccc}
r_{11} & \cdots & r_{1 j} \\
\vdots & \ddots & \vdots \\
r_{i 1} & \cdots & r_{i j}
\end{array}\right]
$$


9. Hasil akhir nilai preferensi (Vi) diperoleh dari penjumlahan dari perkalian elemen baris matrik ternormalisasi (R) dengan bobot preferensi (W) yang bersesuaian elemen kolom matrik (W)

$$
V_{i}=\sum_{j=1}^{n} w_{j} r_{i j}
$$

10. Hasil akhir diperoleh dari proses perankingan yaitu penjumlahan dari perkalian matrik ternormalisasi R dengan vektor bobot sehingga diperoleh nilai terbesar yang dipilih sebagai alternatif terbaik sebagai solusi.

\subsection{Technique for Order Of Preference by Similarity to Ideal Solution (TOPSIS)}

Menurut (Kurniasih, S \& Agustian, MS, 2019) yang mengutip pernyataan Nofriansyah \& Defit 2017 menyatakan bahwa "TOPSIS adalah salah satu pengambil keputusan multikriteria. Metode TOPSIS ini memiliki prinsip yaitu memilih alternatif terbaik yang tidak hanya memiliki jarak terpendek dari solusi ideal positif tetapi juga memiliki jarak terpanjang dari solusi ideal negatif'.

Adapun langkah penyelesaian dalam menggunakan metode topsis adalah menurut Nofriansyah dan Defit adalah :

1. Topsis dimulai dengan membangun sebuah matrik keputusan. Berikut adalah contoh sebuah matrik dengan alternatif dan kriteria

$$
D=\left[\begin{array}{ccc}
x_{11} & \cdots & x_{1 n} \\
\vdots & \ddots & \vdots \\
x_{m 1} & \cdots & x_{m n}
\end{array}\right]
$$

Keterangan :

D : Matrik

m : Alternatif

$\mathrm{n}$ : Kriteria

Xij: Alternatif ke -i dan kriteria ke-j

2. Normalisasi matrik keputusan, setiap elemen pada matrik D dinormalisasikan untuk mendapatkan matrik normalisasi R. Setiap normalisasi dari nilai Rij dapat di lakukan dengan perhitungan seperti pada persamaan

$$
r_{i j=} \frac{x_{i j}}{\sqrt{\sum_{i=1}^{m} x_{i j}^{2}}}
$$

Untuk $i=1,2,3, \ldots \mathrm{m}$; 


$$
j=1,2,3, \ldots \mathrm{n} \text {; }
$$

3. Pembobotan pada matrik yang telah dinormalisasikan, Diberikan bobot $\mathrm{W}=$ (w1,w2,...wn), sehingga weighted normalized matrik V dapat dihasilkan seperti pada persamaan

$$
y_{i j}=w_{i} r_{i j}
$$

4. Menentukan solusi ideal positif dan solusi ideal negatif, solusi ideal positif dinotasikan dengan $A+$ dan solusi ideal negatif dinotasikan dengan A-. Menentukan solusi ideal (+) \& (-)

$$
\begin{aligned}
& A^{+}=\left(y_{1}^{+}, y_{2}^{+}, \cdots, y_{n}^{+}\right) \\
& A^{-}=\left(y_{1}^{-}, y_{2}^{-}, \cdots, y_{n}^{-}\right)
\end{aligned}
$$

\section{Keterangan :}

Vij :elemen matrik V baris ke-i dan kolom ke-j

$\mathbf{J}:\{\mathrm{j}=1,2,3, \ldots \mathrm{n}$ dan $\mathrm{j}$ berhubung dengan benefit kriteria $\}$

$\mathbf{J}:\{\mathrm{j}=1,2,3, \ldots \mathrm{n}$ dan $\mathrm{j}$ berhubungan dengan cost kriteria $\}$

5. Menghitung separation measure, separation measure ini merupakan pengukuran jarak dari suatu alternatif ke solusi ideal positif dan solusi ideal negatif.

Separation measure untuk solusi ideal positif

$$
D_{\vec{i}}^{+}=\sqrt{\sum_{j=1}^{n}\left(y_{i}^{+}-y_{i j}\right)^{2}}
$$

Separation measure untuk solusi ideal negatif

$$
D_{\bar{i}}^{-}=\sqrt{\sum_{j=1}^{n}\left(y_{i j}-y_{\bar{i}}^{-}\right)^{2}}
$$

6. Menghitung kedekatan relatif dengan ideal positif, kedekatan relatif dari alternatif A+ dengan solusi ideal A

$$
V_{1}=\frac{D_{i}^{-}}{D_{i}^{-}+D_{i}^{+}}
$$

7. Mengurutkan pilihan, alternatif dapat diranking berdasarkan urutan Ci. Maka dari itu alternatif terbaik adalah salah satu yang berjarak terpendek terhadap solusi ideal dan berjarak terjauh dengan solusi ideal negatif. 


\section{HASIL DAN PEMBAHASAN}

Penelitian diawali dengan mencari beberapa sumber data sebagai bahan /materi yang harus diuji terlebih dahulu, diantaranya adalah menyusun bagaimana hirarki permasalahan yang ada pada PT.Seikou kemudian diterapkan pada langkah-langkah dari setiap metode berdasarkan metode SAW dan TOPSIS agar lebih mudah memahami setiap proses yang akan digunakan.

\subsection{Analisis Metode SAW dan Perancangan metode TOPSIS}

Langkah pertama dalam melakukan perancangan penggunaan metode SAW yaitu menentukan tujuan yang akan dicapai, menyusun hirarki permasalahan kedalam bentuk pemecahan persoalan yang utuh menjadi unsur-unsur meliputi penyusunan kriteria dan pilihan alternatif yang digunakan. Langkah kedua mendefinisikan kriteria dan bobot nilai dari masing-masing kriteria untuk dijadikan tolak ukur dari masalah yang ada, fungsinya agar bisa mepermudah mengetahui rating nilai dari setaiap alternatif yang akan di proses.

Tabel 1. Kriteria dan Bobot

\begin{tabular}{ccc}
\hline Kriteria & Bobot Kriteria & \\
\hline Tes Jait & $35 \%$ & 0,35 \\
\hline Tes Kemampuan Dasar & $25 \%$ & 0,25 \\
\hline Tes Produk & $35 \%$ & 0,35 \\
\hline Tes Kesehatan & $5 \%$ & 0,05 \\
\hline
\end{tabular}

Tabel 2. Detail Bobot

\begin{tabular}{llll}
\hline Tes Jahit & Tes K. Dasar & Tes Produk & Tes Kesehatan \\
\hline $350=1$ & $60=1$ & $350=1$ & Tidak sehat $=1$ \\
\hline $351-399=2$ & $61-70=2$ & $351-399=2$ & Sehat $=4$ \\
\hline $400-499=3$ & $71-89=3$ & $400-499=3$ & \\
\hline$>500=4$ & $90-100=4$ & $>500=4$ &
\end{tabular}

Langkah selanjutnya dari tabel-tabel di atas akan dibuat tabel matriks nilai alternatif, dan menormalisasikan nya. Sehingga tersusun sampai hasil perhitungan dari setiap alternatif yang ada. Setelah diperoleh matriks ternormalisasi kemudian tahap akhir adalah mencari nilai preferensi dengan menambahkan bobot sehingga akhir dari 
penjumlahan tersebut dapat menjadi perankingan untuk setiap alternative nya. Dan dapat diketahui mana saja pelamar yang diterima dalam proses penerimaan karyawan. Dapat di simpulkan dari hasil perhitungan di atas, beberapa alternatif yang lolos tahap seleksi bisa dilihat pada tabel berikut :

Tabel 3. Hasil Akhir Perangkingan

\begin{tabular}{cccc}
\hline ALTERNATIF & NAMA & HASIL & RANKING \\
\hline V2 & Dani & 1 & 1 \\
\hline V10 & Gozi & 0,9125 & 2 \\
\hline V1 & Rafi & 0,85 & 3 \\
\hline V9 & Dewi & 0,825 & 4 \\
\hline V4 & Ayu & 0,7375 & 5 \\
\hline
\end{tabular}

Lima alternatif teratas akan di proses lagi dengan beberapa kriteria baru untuk dapat mengetahui jabatan/posisi yang sesuai menggunakan perhitungan metode TOPSIS. Dimulai dari pemberian nilai untuk setiap kriteria, hal ini sangatlah penting dalam proses menentukan posisi/jabatan. Dari 5 alternatif yang sudah berhasil mengikuti tahap seleksi. Setiap kriteria menjadi tolak ukur perusahaan karena kriteriakriteria tersebut merupakan kegiatan rutinitas sehari-hari yang ada di perusahaan. Serangkaian tahapan dalam metode TOPSIS dibuat mulai dari membuat matriks keputusan sampai dengan hasil akhir yaitu mencari solusi ideal positif dan solusi ideal negatif. Hasil dari Matriks Solusi Ideal Positif dan Negatif dapat ditunjukan oleh tabel 4.

Tabel 4. Hasil Matriks A+ dan A-

\begin{tabular}{lllllll}
\hline $\mathbf{A}+$ & 0,124 & 0,144 & 0,093 & 0,076 & 0,081 & 0,082 \\
\hline $\mathbf{A -}$ & 0,062 & 0,036 & 0,046 & 0,051 & 0,04 & 0,063
\end{tabular}

Sebelum menghitung nilai preferensi peneliti menghitung nilai distance terbobot terlebih dahulu untuk mempermudah mencari V, tahapan ini merupakan tahapan akhir dari metode TOPSIS.

Tabel 5. Hasil Akhir

\begin{tabular}{ccc}
\hline NAMA & TOTAL NILAI & JABATAN \\
\hline DANI & 0,75 & QC \\
\hline GOZI & 0,25 & PACKING \\
\hline RAFI & 0,38 & PACKING \\
\hline RIKA & 0,09 & MAINTANCE \\
\hline DEWI & 0,05 & MAINTANCE \\
\hline
\end{tabular}


Dapat disimpulkan hasil perhitungan kedua metode diatas menghasilkan rekomendasi jabatan untuk 5 pelamar yaitu qc, packing dan maintance.

\subsection{Perancangan Fungsional}

Tujuan akhir dari penelitian ini adalah merancang sebuah aplikasi sistem pendukung keputusan yang dapat membantu pihak perusahaan khususnya bagian HRD untuk membantu dalam memberikan rekomendasi calon pelamar yang akan diterima dan menentukan Posisi/Jabatan nya.

Selesah melalui tahapan perancangan kedua metode SPK (SAW dan TOPSIS) Langkah berikutnya adalah merancang fungsionalitas menggunakan tools UML, adapun tools yang digunakan mulai dari usecase Diagram, Activity Diagram, Class Diagram, Sequence Diagram dan Deployment Diagram.

Pemodelan aliran kegiatan dalam aplikasi ini digambarkan dengan menggunakan Activity Diagram, dimana untuk memodelkan aliran kerja atau aktivitas dan operasi.akan dijelaskan secara visual menggunakan uraian (workflow).

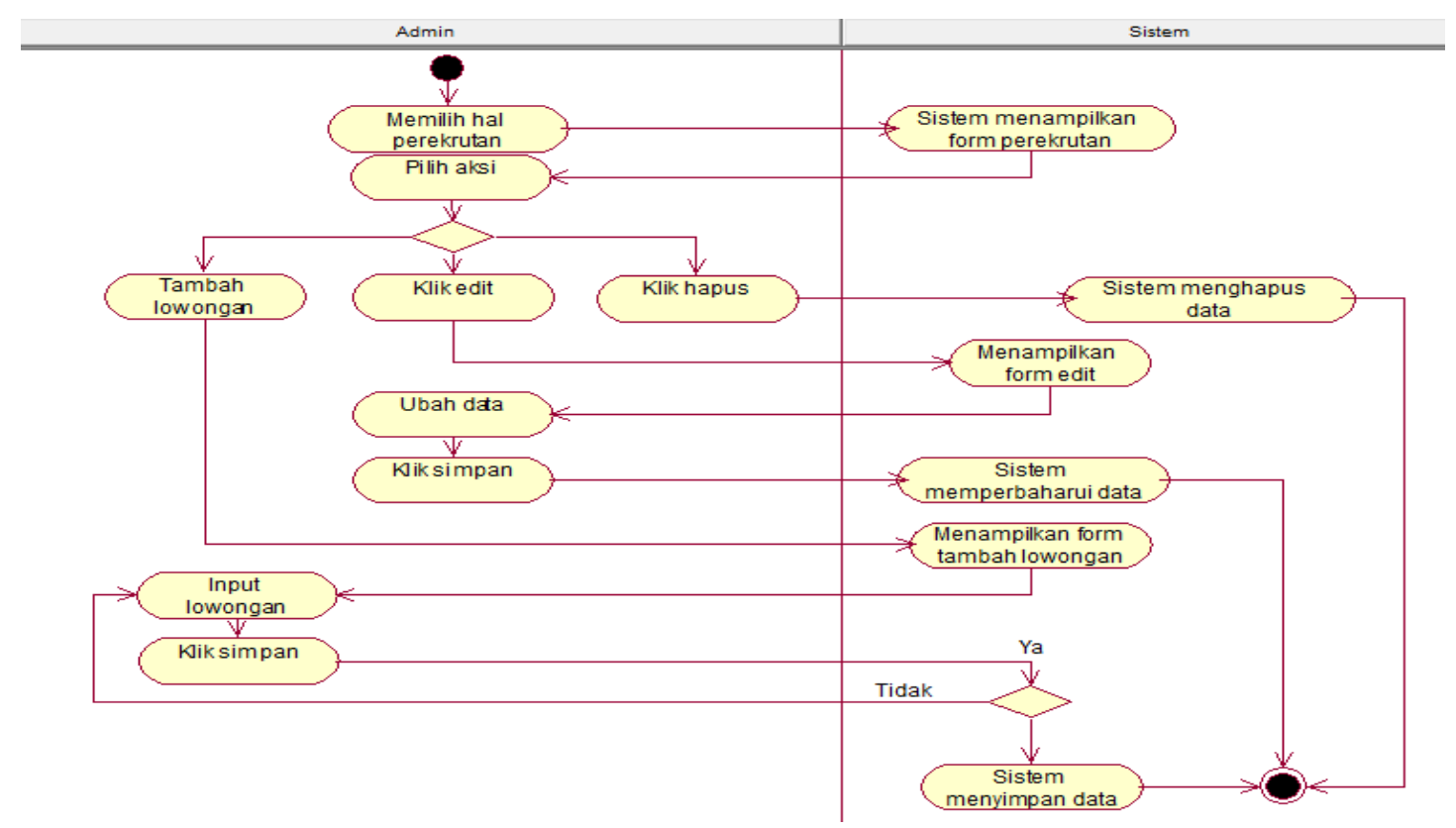

Gambar 1: Activity Diagram Kelola Perekrutan 
Berikut gambaran Class Diagram dari usulan aplikasi yang dirancang.

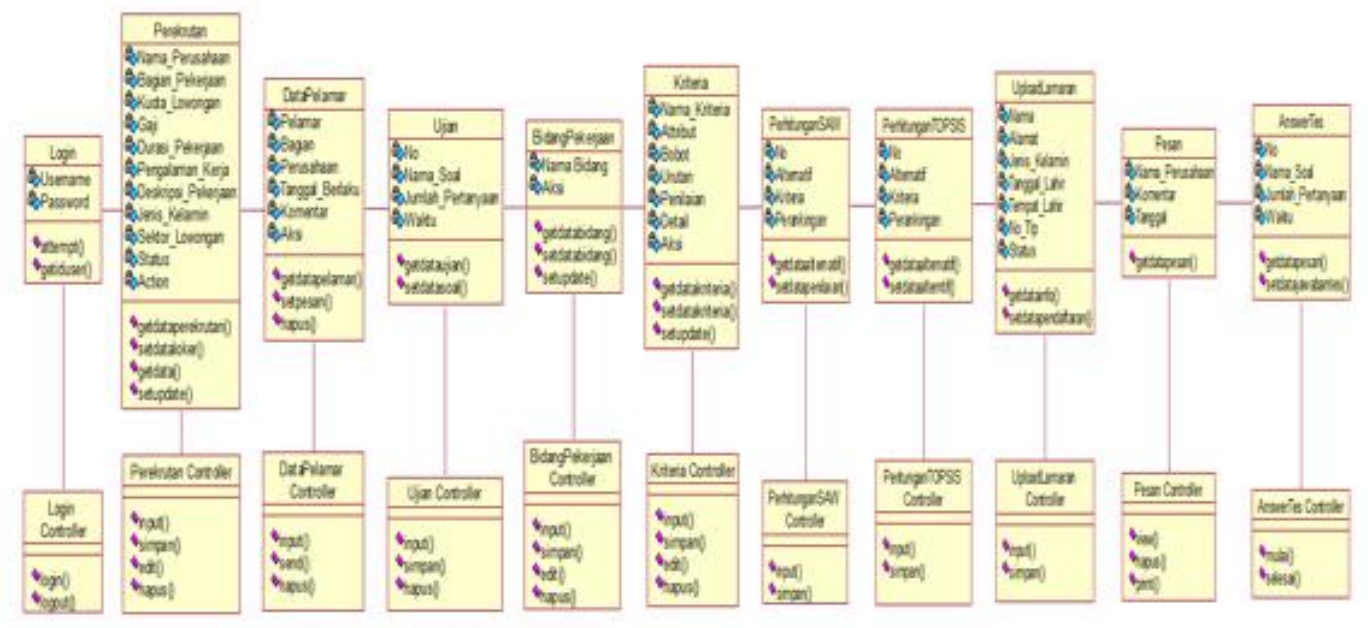

Gambar 2: Class Diagram

Perancangan selanjutnya adalah bagaimana membuat rancangan antarmuka yang bertujuan untuk memberikan gambaran mengenai bentuk antarmuka dari perangkat lunak yang akan digunakan oleh user. Perancangan antarmuka ini mempertimbangkan berbagai kemudahan dan fungsionalitas dari perangkat lunak itu sendiri.

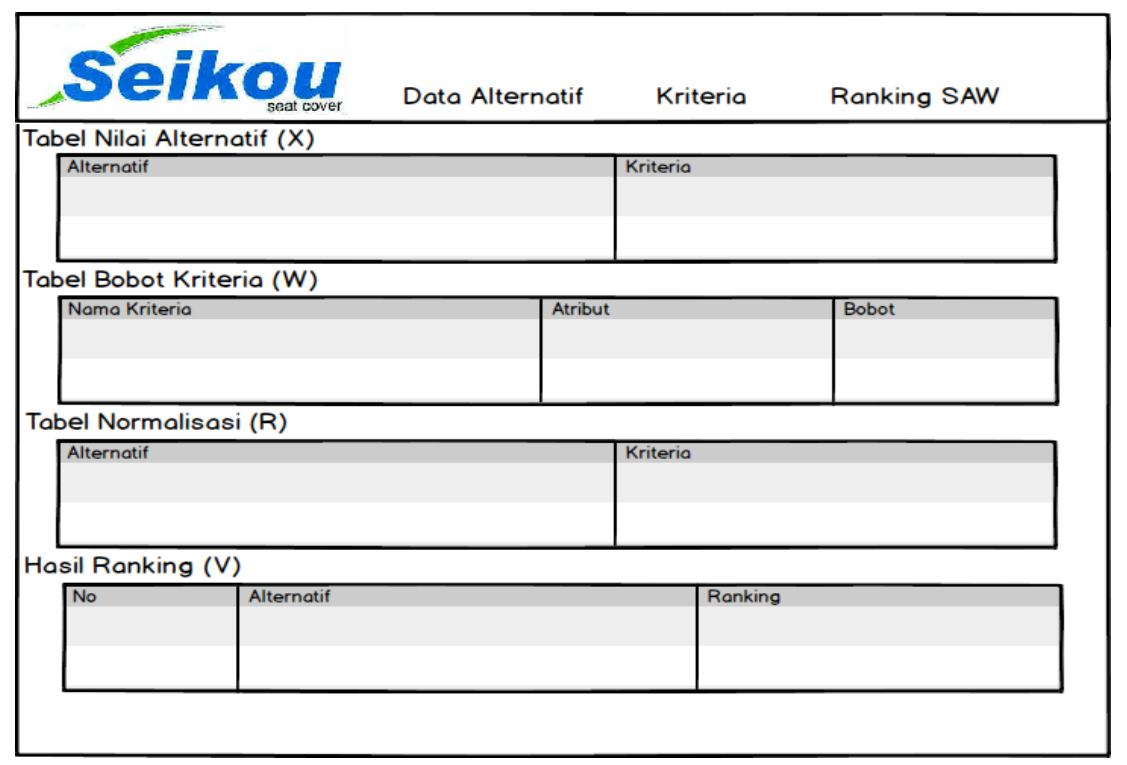

Gambar 3: Perancangan Antarmuka Perhitungan SAW 


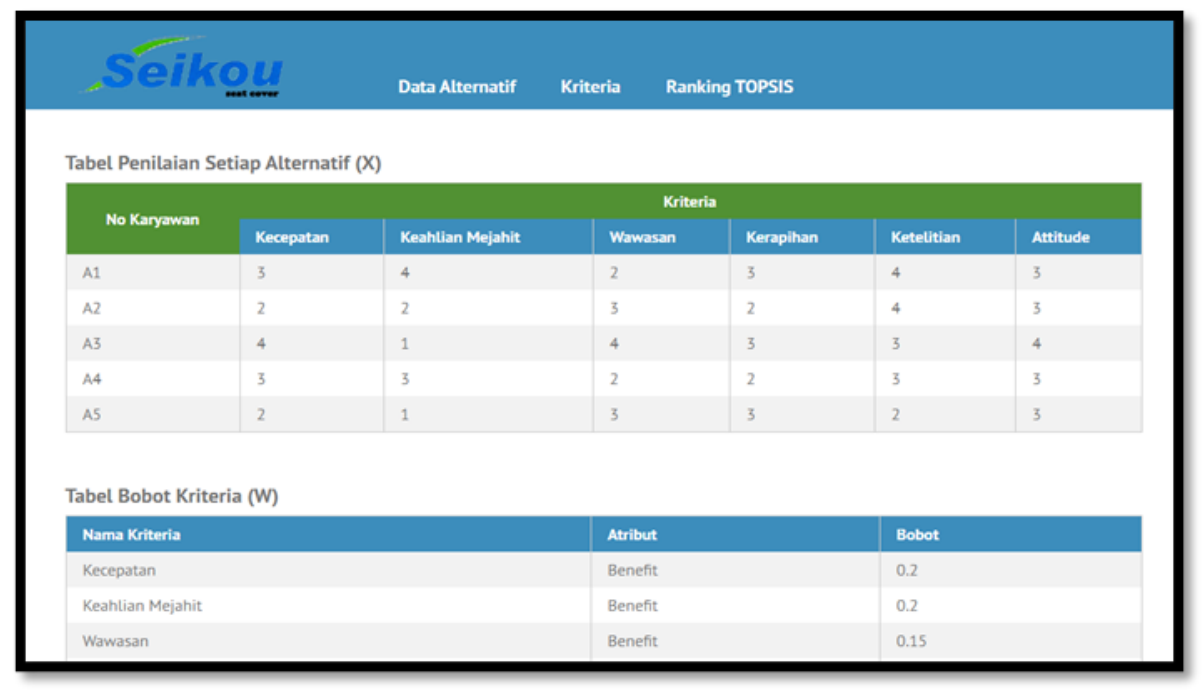

Gambar 4: Implementasi Perhitungan TOPSIS

\section{SIMPULAN}

Dengan penerapan kedua metode (SAW dan TOPSIS) dalam penelitian ini, dapat disimpulkan bahwa dari hasil pengujian terhadap beberapa contoh data pelamar yang ada, sistem pendukung keputusan ini berhasil melakukan perankingan dari setiap alternatif yang ada secara otomatis dan dapat menentukan posisi/jabatan dari alternatif yang terpilih dengan cepat, sehingga dapat membantu perusahaan (bagian HRD) dalam mengelola data pelamar dan mempermudah proses perhitungan serta kelulusan calon karyawan dengan cepat dan sesuai dengan kebutuhan bagian HRD

Adapun saran yang diberikan peneliti dalam upaya pengembangan sistem pendukung keputusan ini, adalah penelitian dilanjutan untuk membahas secara rinci bagaimana menghitung secara lengkap setiap tahapan dalam proses perekrutan karyawan misalnya dalam tahapan training dan lain-lain, diharapkan pula sistem baru nanti dapat juga dilakukan untuk kenaikan jabatan karyawan yang ada di perusahaan PT.Seikou.

\section{DAFTAR PUSTAKA}

Eniyati, S. (2011). Perancangan Sistem Pendukung Pengambilan Keputusan untuk Penerimaan Beasiswa dengan Metode SAW (Simple Additive Weighting). Jurnal Teknologi Informasi DINAMIK Volume 16 Nomor 2 Juli, 172. 
Kusumadewi, S. (2006). Fuzzy Multi-Attribut Decision Making (Fuzzy MADM). In S. Hartati, A. Harjoko, \& R. Wardoyo, Fuzzy Multi-Attribut Decision Making (Fuzzy $M A D M)$ (pp. 78-79). Yogyakarta: Graha Ilmu.

Kurniasih, S \& Agustian, MS. (2019). PENERAPAN METODE AHP DAN TOPSIS UNTUK MENENTUKAN REKOMENDASI LAHAN TAMAN LINGKUNGAN. Jurnal Komputer Bisnis, 12 (2), 7-13.

Kurniasih, S \& Astuti, SP. (2020). KELAYAKAN PENERIMAAN BANTUAN PANGAN NON TUNAI (BPNT) MENGGUNAKAN METODE SIMPLE ADDITIVE WEIGHTING (Studi Kasus: KEL. MEKARJAYA KEC. RANCASARI BANDUNG). Buffer Informatika, 6 9, 47-55.

Nofriansyah, D. (2015). Konsep Data Mining Vs Sistem Pendukung Keputusan. Yogyakarta: DEEPUBLISH.

Nofriansyah, D., \& Defit, S. (2017). MULTI CRITERIA DECISION MAKING (MCDM) pada Sistem Pendukung Keputusan. Yogyakarta: Deepublish. 